\title{
The Effort To Increase Self Confidence Of The Competence Of Vocational High Students Through The Motivation: Mindset Entrepreneurship In Supporting Independence Milenialpreneur In The Future
}

\author{
Author \\ Vembri Aulia Rahmi (Orcid ID. 0000-0001-8407-6448), \\ Hadi Ismanto (Orcid ID. 0000-0002-8767-9081), \\ Nanang Bagus Setiawan (Orcid ID. 000-0002-8625-0857) \\ Correspondence \\ Universitas Muhammadiyah Gresik \\ Email: vembriaulia@umg.ac.id
}

\begin{abstract}
The Community service activities targeting students and teachers of Semen Gresik Vocational Schools are conducted to increase confidence in student competencies, including through the introduction, understanding, and strengthening motivation "Mindset Entrepreneurship" in the school environment. The purpose of the initial community service activity was aimed at responding to complaints about the problems of the school in academics (universities) that vocational student graduates were not working in the area of expertise possessed by students and also only a few students were able to create their jobs. The method used in community service uses an interpersonal approach to teachers and students using in-depth interviews with students and also teachers, interactive socialization, and discussion. The results of community service activities with Semen Gresik vocational partners provided positive results, both according to the perception of teachers and students, namely: (1) an increase in understanding of the problems along with finding solutions for teachers on the causes of low entrepreneurial interest for vocational students; (2) mental growth of students' confidence from their competence, after experiencing a strengthening of motivation on the principle of entrepreneurship (3) increasing insight and knowledge for students and teachers on the important role of entrepreneurship in the current digitalization era.
\end{abstract}

Keywords: Competence, Self Confidence, Entrepreneurship Mindset, Millennial Entrepreneur

Received: 02 May 2020. Accepted: 4 August 2020

\section{Introduction}

The increasing number of students of SMK (Vocational High School) exceeds the proportion of high school students (Senior High School) should prove that the decreasing unemployment rate in Indonesia as a result of the ability and skills of human resources has been fulfilled. However, reality, on the contrary, is the era of disruption that causes many productive ages to be unable to meet job qualifications and unable to create jobs. As it is known that SMK graduates are equipped with the competence of skilled workers and are expected to be able to meet the needs of the industrial world as company workers and complete the needs of the business world by creating their jobs for the benefit of many parties. The inadequate competency of vocational students in the work world is now a problem issue in Indonesia. Similarly, the condition of the problem is almost the same for graduates of Semen Gresik Vocational School.

Based on information from the school, especially teaching staff and school principals, it is known that the output of Semen Gresik Vocational School students also works a lot in the area of expertise, even though the school curriculum has directed students towards competencies according to students' interests. The number of Semen Gresik Vocational School graduates who are job seekers is far greater than the number of their creators. The findings are that students as entrepreneurs, especially entrepreneurs do not continue in the field of business from the skills learned at school. The phenomenon of this change occurred around the estimate in the last two years of graduation since 2017. 
The instructors, especially teachers in the field of counseling guidance as well as entrepreneurship teachers in SMK Semen Gresik expressed their complaints to academics (universities) during a comparative study visit that the SMK students lacked have confidence in his competence. This certainly becomes a challenge for schools to be able to produce their students as graduates with sustainable business skills and independence in the future. Academics, especially lecturers also must be responsible for the community to share knowledge and experience. The success of printing successful millennial generations is the responsibility of stakeholders, namely teachers, government, academics, and the private sector. Parents also give a role as a supporter of student success.

The failure of schools to produce entrepreneurial graduates makes vocational schools a "scapegoat" causing increased unemployment(https://mediaindonesia.com/read/ detail/256776dilema-program-revitasi-smk).

Originally the SMKs need to think about revitalizing the concepts of teaching to students that can be done by conducting collaborations or partnerships with parties outside the school. The cooperation between SMKs and external parties of the school can have a positive impact on all groups, both schools, teachers, students, and the community. The form of cooperation begins with the signing of the MoU contract by the two parties who agreed, with various partnership programs, such as synchronization of the curriculum, industry visits, guest teachers, and work practices (Yalianto and Sutrisno, 2015).

One of the school partnership programs is also carried out by Semen Gresik Vocational School, which includes campus visits as a follow-up form of cooperation with external parties. Following up on the program partnership school, the service activities by the entrepreneurial lecturer team were particularly carried out. The basis for the consideration of community service activities is the situation that the level of confidence of Semen Gresik Vocational School students regarding expertise competencies, particularly in the technical field is still considered weak, as evidenced by the interest of graduates for entrepreneurship that is not yet high, and if there is a level of entrepreneurship students, then the chosen business sector is not in the learned while attending vocational high school. To increase efforts to arouse students' confidence in their potential and competence, it is necessary to strengthen motivation from outside the school.

Confidence can be done by holding intensive counseling. Counseling services are carried out by building effective communication (Imro'atun, 2017). Efforts to increase student confidence through lecturer devotion activities are a form of implementing the motivation of educators towards students by creating selfconcepts. The concept of self is created on the perception of someone in looking at himself, namely through positive self-concept will affect self-confidence and good influence (Armas, Unde, \& Fatimah, 2017). A person's confidence in his ability to complete work is termed self-efficacy, that is, motivation is stronger based on what is believed by oneself than the truth that occurs. High self-efficacy will affect one's entrepreneurial interest. (Purwanto, 2016).

The Semen Gresik Vocational School expects that cooperation with the university can provide motivation for students, especially to strengthen students' mentality to interpret the principles of entrepreneurship in all areas of life. Motivation plays a role in building students' selfconfidence mentality as one of the characteristics of an entrepreneur (Alma, 2017). Based on motivational theories of McClelland's opinion that someone will make an effort to achieve the needs of his achievement. Community service activities will provide additional insight because students gain knowledge from speakers, namely lecturers of service (Prihastiwi, Army, Fatimah, 2018). Based on the background and problems that occur, the community service activities at Semen Gresik Vocational School are deemed necessary to be carried out, not only seen as the fulfillment of the tri dharma of the tertiary institution, but also a form of a sense of responsibility supporting the success of the education sector to print millennial future.

\section{Method}

The method of implementing community service activities at Semen Gresik Vocational School is carried out with an interpersonal approach, both to teachers and students to find out the situational 
weaknesses and shortcomings that are owned by students. The implementation of community service begins with interviews with several teachers and principals. Furthermore, the strengthening of motivation is given by entrepreneurship socialization. The service activity ended with questions and answers and discussion between the speaker and students.

Coordination of a series of socialization processes with previous students through communication with the teacher after the activity is carried out is of partial assistance. Next will continue with the type of ongoing school collaboration activities, such as other entrepreneurship programs. Evaluation of service activities is assessed by several indicators, including attendance of participants to assess participant involvement, discussion activeness measuring student responses, identification of entrepreneurial interests to see.

\section{Results and Discussion}

Community service is carried out by a series of activities as follows:

\section{Coordination and Mentoring of Semen Gresik} Vocational School

Before carrying out core community service activities which include, strengthening the motivation of the "entrepreneurship mindset", coordination is held between the service team and the teachers and the school principal. Coordination is intended to find out problems and limitations in schools so that the university can prepare material that will be presented to Semen Gresik vocational students. To get clear information about students' conditions, interviews with several teachers in the field of entrepreneurship and the management of school counseling and guidance were carried out several times over time, given the busy schedule of teaching activities and the limitations of school administration schedules.

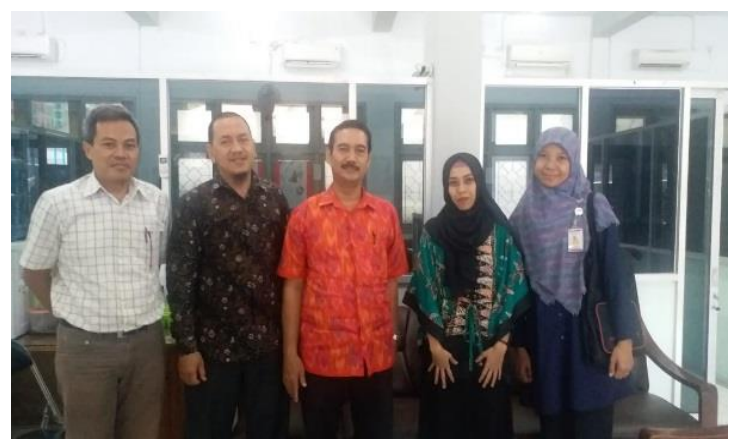

Figure 1. Teacher Coordination with Lecturers

The initial arrival of Semen Gresik Vocational School teacher representatives to Muhammadiyah University Gresik intends to conduct a comparative study and request for cooperation in school programs. This will be followed by academics in coordination with Semen Gresik Vocational School to understand problems in the field. It is known that based on school data that in the last two years, graduates of Semen Gresik Vocational School working or entrepreneurship do not match the field of competency studied in school. This became the concern of the school that the achievement of the school vision was not maximized enough.

Information obtained from the school states that students already have competencies according to their interests, but the confidence (efficacy) for entrepreneurship according to their skills is still weak. Assistance by academics (universities) is done by building intensive communication with the teacher, such as sharing teaching experiences and sharing knowledge on the basics of entrepreneurship. To strengthen confidence in teacher opinion, the service team also conducted special interviews with several graduates of Semen Gresik vocational students. Information gathering from teachers and alumni is expected to be taken into consideration to analyze problems and share new insights in preparation for further service activities with different activities.

\section{Strengthening Motivation Socialization}

Referring to the problems of students, the focus of community service is done by strengthening the motivation "mindset entrepreneurship". Participants in the socialization were students of Semen Gresik Vocational High School in the final grade class. The school hopes that students have the 
knowledge and entrepreneurial spirit before completing their school. The socialization activity was opened (Figure 2) by the vice-principal in the field of public relations and then filled with presenters three entrepreneurial lecturers in turn. Motivation socialization material "mindset entrepreneurship", includes enthusiasm, personality, attitudes, and forms or forms of entrepreneurship. The socialization aims to give students an understanding that success is not merely in the business world, but in all areas of life.

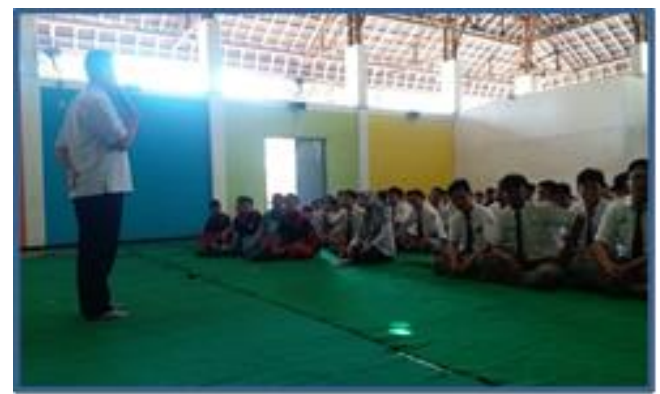

Figure 2. Opening of Socialization by Teachers

Students are directed to open their minds about the importance of the role of entrepreneurship. The enthusiasm of students at Semen Gresik Vocational School to participate in the socialization of strengthening motivation is quite high, as evidenced by many students asking questions as a sign of curiosity over the principle of entrepreneurship. The teachers view that students need motivation from external parties so that students have new confidence and enthusiasm in learning and applying the principles of entrepreneurship. As is well known that students experience boredom and want variations on learning activities in school, where so far learning activities are more on technical skills in the field. Figure 3 below shows the response of students' curiosity to follow the socialization of strengthening the mindset of entrepreneurship.
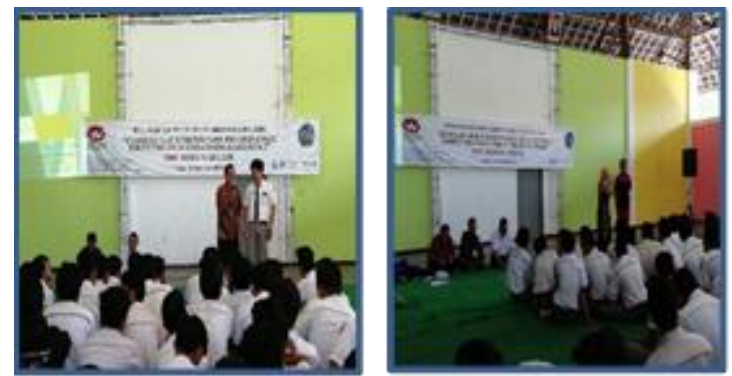

Figure 3. Student Response of Participants in Training.

The socialization activity of strengthening motivation lasted for two hours with 126 students participating in Semen Gresik Vocational School. Students get more insight from the speaker. Sharing experiences by the speaker is not only a theoretical concept, but students are given direction to think analytically about the world of work and the world of entrepreneurship so that students have alternatives to be able to make decisions for their future by considering their worthiness and not just following the desires of certain groups. The obstacle faced during the socialization took place was the noise of students caused by students in one large and open room, so that students who were seated in the back position tended to create noise and disturb the participants who concentrated on following the socialization. Students are allowed to ask questions about any entrepreneurial issues.

Students are given an understanding of the material about the world of business and the world of work. The concept of entrepreneurship in the two fields is also explained how it is implemented in the field. Occasionally the speaker asked questions to the participants of the socialization to measure the concentration of students in understanding the lesson. The confidence of Semen Gresik Vocational School students is still not high enough, as seen from some students having doubts in answering questions, so the speaker must stimulate students to be willing to answer questions. During the discussion, it appears that some students are still shy to ask questions and are active in responding to questions. 


\section{Evaluation and Feedback Activities}

The final community service activity is an evaluation of a series of programs that were planned at the initial stage of service after indicating the problem and its causes. The evaluation phase is carried out one month after the socialization of strength ening the "entrepreneurship mindset". The speaker team asked the vocational teacher Semen Gresik again about student responses and plans for follow-up on the entrepreneurship program for schools. The teacher responded positively to the response of students after participating in the socialization of strengthening motivation and there was a desire to follow up on efforts to increase entrepreneurship motivation for Cement Vocational students.

Based on information from teachers, it is known that some students at Semen Gresik Vocational School have passions different in making choices after graduating from school and not all students want to become entrepreneurs. Feedback on the promotion of motivational strengthening is to follow up with in-depth activities on other entrepreneurial concepts, such as: completing the curriculum of the basic material of school entrepreneurship theory with the basic material of entrepreneurial practice, so students can apply and adjust technical skills competencies with the principles of entrepreneurship.

Vocational students are expected to be able to identify what excellence they have and of course, it can be used as support to create added value in facing future life challenges. The entrepreneurship principle that is instilled by the teacher to students enables it to produce feedback so that students become an independent generation in the current era of disruption. Community service at Semen Gresik Vocational School forms a synergy of mutualism between teachers and lecturers to share information and experiences on how to print and educate graduates as prospective entrepreneurs.

The results of the evaluation of the socialization activities prove that the confidence of Semen Gresik Vocational School students has changed for the better, even though the improvement does not look drastic. Information from the teacher shows that students have the attitude of initiative in class and seem more eager to follow the lesson. The coordination of the speakers with the tutor continues to be done to find out how much influence the strengthening of motivation on the level of student confidence in competence. Achievement of the delivery of the entire socialization material reinforcement of the motivation "mindset entrepreneurship" has been carried out according to plan, it's just that time constraints and a large number of participants can not accommodate all student questions about entrepreneurship.

Realizing the limited time and some additional entrepreneurial materials that still need to be completed, the results of the feedback from the school stated that for Semen Gresik Vocational School students who have a passion to become entrepreneurs will need ongoing assistance. The school intends to facilitate student needs regarding business practices for entrepreneurs millennials. The school curriculum is prepared to plan to prepare certain activities to learn practical entrepreneurship in collaboration with academics, so students have mental reinforcement and self-confidence as an entrepreneur later.

The target of community service to students and teachers of Semen Gresik Vocational School is considered successful by looking at the indicators of feedback that show that teachers find the causes and solutions to problems regarding the lack of confidence in the competency skills of Semen Gresik Vocational School students. Students also get mental reinforcement and additional insight by presenters as well as business practitioners. Community service by universities also supports the implementation of the Semen Gresik Vocational Program in conducting school cooperation and partnerships.

\section{Conclusion}

Vocational School Achievement in completing graduate students by the expectations of the government to overcome the problem of unemployment in Indonesia requires the support of various parties. One of them is through optimization of cooperation and synergy with stakeholders educational, in this case, the school's external parties as stakeholders of Semen Gresik Vocational School graduates. The problems of 
Semen Gresik Vocational School students in the last two years which show that graduates of students working and entrepreneurship are not by their field of expertise are influenced by: first, the situational conditions in the era of disruption such as the present cause students to take all available employment opportunities, secondly, students' confidence in their competence is still weak with the high level of competition in the industrial era 4.0, third, lack of mental reinforcement and motivation "mindset entrepreneurship" at Semen Gresik Vocational School.

Community service through a series of activities that support the understanding of entrepreneurship has a positive impact on schools, teachers, and especially students. Strengt hening motivation through socialization themed "mindset entrepreneurship" has a positive impact, primarily intended as an effort to increase student confidence incompetence, in the form of skills that have a sale value. The socialization will strengthen students with their potential to hold the principles of entrepreneurship in all areas of life.

The teacher can adjust the curriculum of entrepreneurship theory with entrepreneurial practice in the business world. Schools can realize collaborative programs with external parties to share information and exchange new experiences in building entrepreneurial foundations for the millennial generation. The implementation of community service not only fulfills the obligations in implementing the tri dharma of higher education but also supports the entrepreneurship program in the community, as well as sharing benefits in the development of sustainable education.

\section{Suggestion}

An entrepreneurial program will be easily implemented if entrepreneurship-based activities and strengthening entrepreneurial motivation can be carried out sustainably, bearing in mind that entrepreneurs are not sufficiently armed with theories of capital and skills, but the mental strengthening of students through motivation can have a positive effect. For students to be able to start entrepreneurship, the school should facilitate students in business assistance by business practitioners, so that they can consult business problems regularly. If a passion student becomes an industrial worker, then the school should prepare to collaborate to accommodate graduates who are interested in working in the industrial world while still providing students with the concept of entrepreneurial workers, so students can be productive and consistent in the world of industrial work.

\section{References}

Alma, B. 2017. Entrepreneurship. Bandung: Alfabeta.

Armas, AM, Unde, AA, Fatimah, JM. 2017. Self Concept and Communication Competency of Persons with Disabilities in Fostering Confidence and SelfActualization in the World of Entrepreneurship in Makassar City. KAREBA: Journal of Communication Studies, 6(2), 277-284.

Imro'atun, S. 2017. The Effectiveness of Group Counseling Services to Increase Junior High School Student Self Confidence. Journal of Guidance and Counseling Studies, 2(2), 50-57.

Prihastiwi, DA, Army, Y., Fatimah, AN. 2018. Optimizing the Role of Vocational Schools as Printers of Young Entrepreneurs through Strengthening Motivation and Provisioning Entrepreneurial Skills and Knowledge. Paper presented at the Proceedings of the Unimus National Seminar. 
Purwanto, F. 2016. The Effect of Self-Efficacy, Entrepreneurship Knowledge, and Entrepreneurial Motivation on Entrepreneurial Student Interest (Study of the Sailing Diploma Students at the University of Hang Tuah Surabaya).

Yalianto, Y., Sutrisno, B. 2015. Management of School Collaboration with Business World / Industrial World (Study Site of SMK Negeri 2 Kendal). Journal of Social Sciences Education, 24(1), 19-37. 